\title{
HUBUNGAN ANTARA PENGUASAAN KOSAKATA DAN STRUKTUR KALIMAT DENGAN KEMAMPUAN MENULIS KARANGAN NARASI
}

\author{
Rintik Sunariati ${ }^{1}$, Esti Ismawati ${ }^{2}$, Iswan Riyadi ${ }^{3}$ \\ ${ }^{123}$ Pascasarjana Unwidha Klaten \\ email korespondensi: estisetyadi@gmail.com
}

\begin{abstract}
Abstrak
Penelitian ini bertujuan untuk menemukan ada tidaknya korelasi antara penguasaan kosakata dan struktur kalimat dengan kemampuan menulis karangan narasi di Kelas IV SD Muhammadiyah PK Rabbani Klaten Tahun 2018/2019. Penelitian Studi Korelasional ini menggunakan teknik pengumpulan data berupa tes dengan tiga variabel, yakni X1 penguasaan kosakata, X2 penguasaan struktur kalimat, dan Y karangan narasi.Teknik analisis data dengan korelasi Product Moment, korelasi parsial, dan regresi ganda dengan taraf signifikan 0,05. Dari hasil analisis disimpulkan bahwa ada korelasi antara X1 dengan $\mathrm{Y}$ dengan koefisien korelasi sebesar 0,771. Ada korelasi antara X2 dengan Y dengan koefisien sebesar 0,441. Ada korelasi antara X1 dan X2 dengan $\mathrm{Y}$ dengan koefisien sebesar 0,884. Penguasaan kosakata memberikan sumbangan terhadap kemampuan menulis karangan narasi sebesar $59,16 \%$, penguasaan struktur kalimat memberikan sumbangan terhadap kemampuan menulis karangan narasi sebesar 19,01\%. Sumbangan penguasaan kosakata dan struktur kalimat terhadap kemampuan menulis karangan narasi sebesar 78,17\%.
\end{abstract}

Kata Kunci: penguasaan kosakata, struktur kalimat, karangan narasi

\begin{abstract}
This study aims to find the correlation between vocabulary mastery and sentence structure with the ability to write narrative essays in Class IV SD Muhammadiyah PK Rabbani Klaten in 2018/2019. This Correlational Study Research uses data collection techniques in the form of tests with three variables, namely X1 mastery of vocabulary, X2 mastery of sentence structure, and $\mathrm{Y}$ narrative composition. Data analysis techniques with Product Moment correlation, partial correlation, and multiple regression with a significant level of 0.05 . From the analysis it was concluded that there was a correlation between $\mathrm{X} 1$ and $\mathrm{Y}$ with a correlation coefficient of 0.771 . There is a correlation between $\mathrm{X} 2$ and $\mathrm{Y}$ with a coefficient of 0.441 . There is a correlation between $\mathrm{X} 1$ and $\mathrm{X} 2$ with $\mathrm{Y}$ with a coefficient of 0.884 . Mastery of vocabulary contributed to the ability to write narrative essays by $59.16 \%$, mastery of sentence structure contributed to the ability to write narrative essays by $19.01 \%$. Contribution of vocabulary mastery and sentence structure to the ability to write narrative essays is $78.17 \%$.
\end{abstract}

Keywords: vocabulary mastery, sentence structure, narrative essays 


\section{PENDAHULUAN}

Penguasan kosakata dan struktur kalimat bahasa Indonesia sangat penting dalam penguasaan keterampilan berbahasa, khususnya menulis. Menurut Iskandarwassid (2015: 248) aktivitas menulis merupakan suatu bentuk manifestasi kemampuan dan keterampilan berbahasa yang paling akhir dikuasi oleh pembelajar bahasa setelah kemampuan mendengarkan, berbicara, dan membaca. Penguasaan kosakata siswa rendah, hal ini menyebabkan siswa sulit menuangkan idenya, sulit menyusun, merangkai kata, dan sulit menggunakan variasi kalimat dalam menulis karangan.

Pengusaan kosa kata yang baik akan memberi dampak pada wawasan dan pengetahuan kosakata yang luas sehingga diharapkan dapat menyusun kalimat secara lebih baik. Keterampilan menulis narasi memerlukan penguasaan struktur kalimat yang baik. Munirah \& Hardian (2016 :78-87) serta Doyin dan Wagiran (2009: 18) mengemukakan bahwa karangan narasi dipilih jika penulis ingin bercerita kepada pembaca mengenai peristiwa yang disusun berdasarkan urutan waktu atau urutan kejadian. Dikarenakan perantaraan kalimatlah seseorang dapat menyampaikan ceritanya dengan lengkap dan jelas. Penguasaan struktur kalimat siswa memiliki pengaruh terhadap keterampilan menulis. Jika siswa tidak memiliki penguasaan yang baik mengenai struktur kalimat, maka ia akan mengalami kesulitan dalam menceritakan kronologis cerita yang ingin disampaikan pada pembaca. Munirah \& Hardian (2016 :78-87) mengemukakan penguasaan kosa kata dan struktur kalimat merupakan dua komponen yang saling berkaitan terus.

Permasalahan yang akan dipecahkan dalam penelitian ini adalah, (1) adakah hubungan antara penguasaan kosakata dengan kemampuan menulis karangan narasi siswa Kelas IV SD Muhammadiyah PK Rabbani Kecamatan Karanganom Kabupaten Klaten Tahun Pelajaran 2018/2019? (2) Adakah hubungan antarapenguasaan kalimat dengan kemampuan menulis karangan narasi siswa Kelas IV SD Muhammadiyah PK Rabbani Kecamatan Karanganom Kabupaten Klaten Tahun Pelajaran 2018/2019? (3) Adakah hubungan antara penguasaan kosakata dan kalimat dengan kemampuan narasi siswa Kelas IV SD Muhammadiyah PK Rabbani Kecamatan Karanganom Kabupaten Klaten Tahun Pelajaran 2018/2019? 


\section{Penguasaan Kosakata dan Struktur Kalimat}

Djiwandono (2011: 126) menjelaskan bahwa kosakata diartikan sebagai perbendaharaan katakata dalam berbagai bentuk yang meliputi kata-kata lepas dengan atau tanpa imbuhan dan kata-kata yang merupakan gabungan dari kata-kata yang sama atau berbeda, masing-masing dengan artinya sendiri. Abdul Chaer (2011: 131) menyatakan kosakata Bahasa Indonesia adalah semua kata yang terdapat dalam bahasa Indonesia.

Tarigan (2015: 2) mengemukakan kualitas keterampilan berbahasa seseorang bergantung kepada kuantitas dan kualitas kosakata yang dimilikinya. Semakin kaya kosakata yang kita miliki, semakin besar pula kemungkinan kita terampil berbahasa. Kuantitas dan kualitas kosakata seorang siswa turut menentukan keberhasilannya dalam kehidupan. Menurut Munirah \& Hardian (2016 78-87) kosakata memegang fungsi dan peranan yang sangat penting dalam keterampilan berbahasa. Kosakata dapat menambah ilmu bahasa seseorang sehingga pengetahuan yang dimiliki semakin luas.

Menurut Carpenter \& Olson (dalam Sitompul, Elsa Yusrika, 2013:52) kosakata adalah komponen penting dalam pembelajaran bahasa kedua / asing karena diperlukan untuk mengekspresikan makna dan menyampaikan pikiran melalui keterampilan reseptif dan produktif. Selanjutnya, Cameron (dalam Sitompul, Elsa Yusrika, 2013:52) percaya bahwa kosakata adalah pusat pembelajaran bahasa di tingkat dasar untuk memperkaya bahasa peserta didik. Dengan demikian, harus ada strategi untuk membantu siswa belajar kosa kata.

Kompetensi inti menyajikan pengetahuan faktual dalam bahasa yang jelas, sistematis, dan logis dalam karya yang estetis dalam gerakan yang mencerminkan anak sehat, dan dalam tindakan yang mencerminkan perilaku anak beriman dan berakhlak mulia. Kompetensi Dasar tersebut mengharapkan siswa mampu menyajikan teks cerita petualangan tentang lingkungan secara tertulis baku dalam bentuk karangan sederhana dengan mempergunakan penggunaan kosakata baku. Indikator kosakata yang digunakan adalah: (1) menunjukkan kata baku dengan uraian yang tersedia; (2) 
menunjukkan sinonim kata yang tersedia; (3) menunjukkan antonim kata yang tersedia; dan (4) menjelaskan arti kata dengan kata-kata atau menggunakan kalimat.

Nurgiyantoro (2014: 338) mengemukakan penguasaan kosakata dapat dibedakan ke dalam penguasaan yang bersifat reseptif dan produktif, yaitu kemampuan memahami kosakata terlihat dalam kegiatan membaca dan menyimak, sedangkan kemampuan mempergunakan kosakata tampak dalam kegiatan menulis dan berbicara. Hal tersebut sesuai dengan pendapat Djiwandono (2011: 126) yang membagi penguasaan kosakata menjadi dua, yaitu penguasaan kosakata yang bersifat pasifreseptif dan aktif-produktif.

Penguasaan kosakata adalah pembendaharaan kata atau kekayaan kata yang dikuasai seseorang. Penguasaan kosakata dalam jumlah yang memadai sangat diperlukan untuk melakukan kegiatan berkomunikasi dengan bahasa. Penguasaan kosakata yang lebih banyak memungkinkan kita untuk menerima dan menyampaikan informasi yang lebih luas dan kompleks (Nurgiyantoro, 2014: 282).

Pada penelitian ini instrument yang digunakan tes penguasaan kosakata yang bersifat aktif-produktif, dibatasi pada bentuk tes subjektif pada kelas IV KD. 4.4 Menyusun teks cerita petualangan tentang lingkungan dengan memperhatikan penggunaan ejaan (huruf besar, tanda titik, tanda koma, dll.), dengan indikator: (1) menunjukkan kata sesuai dengan uraian yang tersedia; (2) menunjukkan sinonim kata yang tersedia; (3) menunjukkan antonim kata yang tersedia; dan (4) menjelaskan arti kata dengan kata-kata atau menggunakan kalimat.

Effendi S, Djoko Kentjono, dan Basuki Suhardi (2015:218) menyatakan bahwa kalimat adalah satuan gramatikal yang disusun oleh konstituen dasar yang umumnya berupa klausa, kata penghubung dan intonasi final. Dalam wujud tulisan huruf latin, kalimat dimulai dengan huruf kapital dan diakhiri dengan tanda titik (.), tanda tanya (?), dan tanda seru (!). Kalimat adalah satuan bahasa terkecil yang dapat mengungkapkan pikiran yang utuh. Pikiran yang utuh itu dapat diekspresikan dalam bentuk lisan atau tulisan.

Sebagai unsur pembangun wacana, kalimat memiliki beberapa bentuk, yaitu kalimat berdasarkan bentuk dan kalimat berdasarkan makna. Kalimat berdasarkan bentuk terdiri atas: kalimat tunggal dan kalimat majemuk, sedangkan berdasarkan 
maknanya terdiri atas: kalimat berita, kalimat tanya, kalimat kalimat seru, dan kalimat empatik (Muslich, 2010). Unsur kalimat adalah fungsi sintaksis yang biasa disebut juga jabatan kata atau peran kata, yaitu subjek $(\mathrm{S})$, predikat $(\mathrm{P})$, objek $(\mathrm{O})$, pelengkap (Pel), dan keterangan (Ket) (Muslich, 2010:126). Kalimat bahasa Indonesia baku sekurang - kurangnya terdiri atas dua unsur, yakni S dan P.

Menurut Dalman (2015: 106) narasi merupakan sebuah cerita yang berusaha menciptakan, mengisahkan, dan merangkaikan tindak tanduk manusia dalam sebuah peristiwa atau pengalaman manusia dari waktu ke waktu, di dalamnya terdapat tokoh yang menghadapi suatu konflik yang disusun secara sistematis. Bedasarkan hal tersebut, dapat diketahui ada beberapa hal yang berkaitan dengan narasi, yaitu: (1) berbentuk cerita atau kisahan; (2) menonjolkan pelaku; (3) menurut perkembangan dari waktu ke waktu; dan (4) disusun secara sistematis.

\section{Pembelajaran Keterampilan Menulis Narasi Di SD}

Menulis merupakan keterampilan berbahasa yang menggunakan ragam bahasa tulis. Menulis merupakan bagian yang tidak dapat dipisahkan dalam sebuah proses belajar yang dialami siswa selama menuntut ilmu di sekolah. Menulis memerlukan keterampilan karena diperlukan latihan yang berkelanjutan. Pembelajaran keterampilan menulis pada jenjang sekolah dasar merupakan landasan untuk jenjang yang lebih tinggi. Siswa sekolah dasar diharapkan dapat menyerap aspek-aspek dasar dari keterampilan menulis, sehingga pembelajaran keterampilan menulis pada jenjang sekolah dasar tersebut berfungsi sebagai landasan untuk keterampilan menulis di jenjang pendidikan berikutnya.

Pengajaran menulis di sekolah dasar dilaksanakan dalam dua tingkatan, yaitu melukis permulaan dan melukis lanjut. Pada tingkat menulis permulaan, kegiatan latihan menulis diawali dengan menulis secara teknis memegang dan menggunakan alat tulis, menulis dan menebalkan huruf, menyalin kata, menulis dengan menggunakan huruf sambung, dan menulis kalimat. Tingkatan kedua adalah menulis lanjut. Pembelajaran menulis lanjut merupakan pembelajaran menulis yang menggutamakan dan menekankan pada penggungkapan pikiran, perasaan, gagasan, pendapat dan perasaan dalam berbagai ragam tulisan. 
Menulis adalah salah satu keterampilan berbahasa yang digunakan seseorang untuk berkomunikasi secara tidak langsung dan tidak secara tatap muka dengan orang lain. Menulis adalah kegiatan produktif dan ekspresif. Dalam bahasa tulis, seorang penulis harus dapat mengungkapkan ide secara jelas, runtut, dan logis.

Kemampuan menulis meliputi tiga aspek, yaitu aspek isi, aspek retorika, dan aspek kebahasaan.Aspek ini mencakup masalah penulisan dan pengembangan ide pokok, pengembangan kalimat utama menjadi paragraf, dan relevansi isi dengan topik. Aspek retorika membahas pengorganisasian ide termasuk di dalamnya teknik penyampaian.Aspek kebahasaan meliputi tata bahasa, diksi, ejaan, dan tanda baca.

Abidin (2012: 181) mengemukakan menulis adalah suatu proses berkomunikasi secara tidak langsung antara penulis dengan pembacanya. Menulis pada dasarnya adalah sebuah proses dimana produk yang dihasilkan seorang penulis diproduksi melalui tahapan-tahapan. Tahapan tersebut dimulai dari tahap pemerolehan ide, pengolahan ide hingga tahap pemroduksian ide. Hal tersebut sesuai dengan pendapat Tarigan (2008: 3) bahwa menulis adalah salah satu keterampilan berbahasa yang digunakan seseorang untuk berkomunikasi secara tidak langsung, tidak secara tatap muka dengan orang lain.

Yunus (2015: 25) berpendapat menulis adalah bertutur kata sesuai dengan gaya sendiri, dari yang diketahui dan dialami. Menulis menjadi alat berbagi ide dan gagasan yang subjektif dari kita kepada orang lain. Berdasarkan uraian tersebut dapat disimpulkan bahwa menulis merupakan keterampilan berbahasa yang memerlukan proses atau tahapan-tahapan dalam mengemukakan gagasan dalam bentuk tulisan agar dipahami oleh orang lain. Tahapan dalam menulis dimulai dari tahap pemerolehan ide, pengolahan ide hingga tahap pemroduksian ide.

Suparno dan Yunus (2008: 3.3) membagi kegiatan mengarang menjadi tiga tahap, yakni: (1) tahap kegiatan prapenulisan (prewriting), (2) tahap kegiatan penulisan (writing), dan (3) tahap kegiatan pascapenulisan (post-writing). Berdasarkan hal tersebut, kegiatan mengarang merupakan kegiatan yang mengikuti alur proses yang bertahap dan berurutan. Jika alur prosesnya berurutan, maka kualitas produk karangan yang dihasilkan akan baik, karena arah penulisan karangan jelas. Clark (dalam Zainurrahman 2011: 11) menyederhanakan langkah-langkah dalam proses menulis 
menjadi tiga langkah Prewriting atau Planning, Writing, dan Rewriting atau Revisi. Dalman (2015: 111-114) mengemukakan jenis narasi ada dua, yaitu narasi ekspositoris dan narasi sugestif.

\section{Narasi ekspositoris (narasi faktual)}

Narasi ekspositoris merupakan jenis karangan narasi yang mengutamakan kisah yang sebenarnya dari tokoh yang diceritakan. Karangan ini menceritakan tokohnya berdasarkan fakta yang dialami tokoh tersebut. Jadi, karangan tersebut tidak boleh fiktif dan tidak boleh bercampur dengan daya khayal atau daya imajinasi pengarangnya. Bahasanya harus menggunakan bahasa yang informatif dengan titik berat pada pemakaian kata-kata denotatif.

\section{Narasi sugestif (narasi artistik)}

Narasi sugestif merupakan karangan yang mengizinkan pengarangnya menggunakan daya khayal atau daya imajinasinya untuk menghidupkan sebuah cerita. Bahasa yang digunakan adalah bahasa konotatif, yaitu bahasa yang mengandung makna kias. Makna atau amanat yang disampaikan pengarangnya masih dalam bentuk tersirat. Narasi sugestif lebih bersifat estetik atau artistik, sehingga menjadi karangan yang menyenangkan untuk dibaca.

Penilaian yang dilakukan terhadap hasil karangan siswa bersifat menyeluruh berdasarkan kesan yang diperoleh dari membaca karangan secara selintas. Aspek yang dinilai dalam menulis karangan yaitu: (1) isi karangan; (2) organisasi isi; (3) kosakata; (4) penggunaan bahasa; dan (5) mekanik (Nurgiyantoro, 2014: 441-442).

Pemilihan bentuk tulisan narasi dalam pembelajaran keterampilan menulis di kelas IV SD disesuaikan dengan kurikulum yang berlaku. Bentuk tulisan karangan narasi yang diajarkan pada sekolah dasar merupakan bentuk tulisan narasi yang disesuaikan dengan perkembangan kognitif maupun perkembangan bahasa siswa kelas IV sekolah dasar yaitu bentuk karangan narasi petualangan sederhana tentang lingkungan.

\section{METODE}

Penelitian ini merupakan studi korelasional dengan menggunakan metode survai pada tiga variable, yakni X1 penguasaan kosakata. X2 penguasaan struktur kalimat, dan Y menulis karangan narasi di Kelas IV SD. Instrumen yang digunakan 
adalah tes kosakata, tes struktur kalimat, dan tes menulis karangan narasi. Instrumen dikembangkan dengan 9 langkah (Ismawati, 2016: 100), mulai dengan membaca teori yang terkait dengan kosakata, struktur, menulis; tetapkan dimensi dan indikator, tetapkan konstruk, tetapkan jenis instrument, validasi pakar, uji coba, analisis hasil ujicoba, merakit tes, ke lapangan.

Teknik analisis data yang digunakan adalah Korelasi Product Moment, korelasi parsial dan regresi ganda. Sebelumnya dilakukan uji prasyarat analisis agar terpenuhi (1) data berskala interval. (2) Pengambilan sampel dari populasi secara random. (3) Masing-masing variableberdistribusi normal. (4) Hubungan antar variable menunjukkan garis linear.

Uji Prasyarat Analisis meliputi uji Normalitas dan Homogenitas serta linearitas.

Uji Normalitas data digunakan One-Sample Kolmogorov-Smirnov Test

Uji Homogenitas digunakan ANOVA Tabel.

Uji Linieritas digunakan analisis varians garis regresi.

Teknik Analisis Korelasi Product Moment

Teknik analisis dengan Korelasi Parsial

Teknik Analisis Regresi Ganda

\section{Diagram Alir Penelitian}

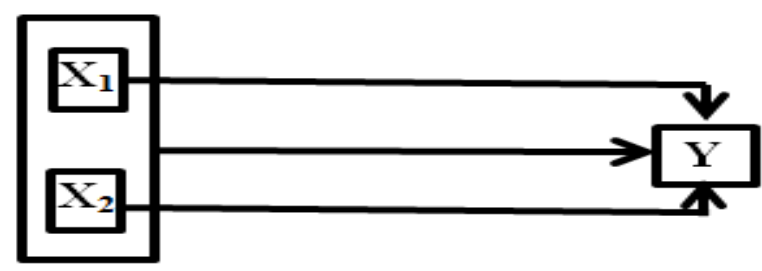

\section{Keterangan}

$\mathrm{X} 1$ = Penguasaan Kosakata

X2 = Penguasaan Struktur Kalimat

$\mathrm{Y}=$ Karangan Narasi

\section{HASIL PENELITIAN DAN PEMBAHASAN}

\section{Hasil Penelitian}

Deskripsi data pada variabel bebas adalah penguasaan kosakata $\left(\mathrm{X}_{1}\right)$ dan kalimat $\left(\mathrm{X}_{2}\right)$, dan kemampuan menulis narasi (Y) meliputi rata-rata skor, modus, median, p-ISSN 2089-2810 e-ISSN 2407-151X 
varians, simpangan baku, distribusi frekuensi, dan histogram. Sebaran data penguasaan kosakata pada Kelas IV SD Muhammadiyah PK Rabbani Kecamatan Karanganom Kabupaten Klaten Tahun Pelajaran 2018/2019 tampak pada tabel berikut.

\begin{tabular}{|c|c|c|c|c|c|}
\hline & & Frequency & Percent & Valid Percent & $\begin{array}{l}\text { Cumulative } \\
\text { Percent }\end{array}$ \\
\hline \multirow{7}{*}{ Valid } & $4-6$ & 4 & 16.0 & 16.0 & 16.0 \\
\hline & $7-9$ & 4 & 16.0 & 16.0 & 32.0 \\
\hline & $10-12$ & 3 & 12.0 & 12.0 & 44.0 \\
\hline & $13-15$ & 9 & 36.0 & 36.0 & 80.0 \\
\hline & $16-18$ & 4 & 16.0 & 16.0 & 96.0 \\
\hline & $19-21$ & 1 & 4.0 & 4.0 & 100.0 \\
\hline & Total & 25 & 100.0 & 100.0 & \\
\hline
\end{tabular}

Data penguasaan kosakataberkisar antara 4 sampai 21 dengan rata-rata 11,80. Penguasaan Kosakata siswa kelas IV SD Muhamamdiyah PK Rabbani ini memiliki skor tertinggi adalah 19, skor terendah 4. Dengan menggunakan kriteria tersebut data tentang penguasaan kosakata terdapat 8 orang siswa (32\%) yang memiliki penguasaan kosakata rendah, sebanyak 12 orang siswa $(48,7 \%)$ termasuk memiliki penguasaan kosakata sedang, dan sebanyak 5 siswa (20\%) memiliki penguasaan kosakata tinggi. Berdasarkan tabel distribusi frekuensi penguasaan kosakata, dapat dibuathistogram frekuensi penguasaan kosakata sebagai berikut.

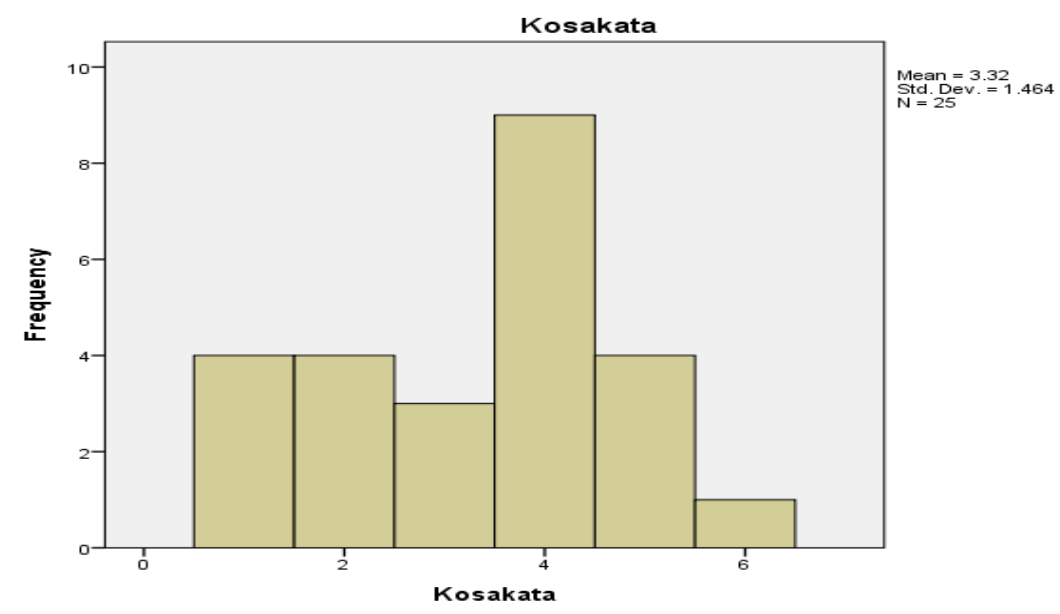

Data penguasaan struktur kalimat berkisar antara 4 sampai 18 dengan rata-rata 10,40. Penguasaan struktur kalimat siswa kelas IV SD Muhamamdiyah PK Rabbani ini memiliki skor tertinggi adalah 17, skor terendah 4. Dengan demikian sebaran data 
penguasaan kalimat pada Kelas IV SD Muhammadiyah PK Rabbani Kecamatan Karanganom Kabupaten Klaten Tahun Pelajaran 2018/2019 tampak pada tabel sebagai berikut.

Kalimat

\begin{tabular}{|ll|l|l|l|l|}
\hline & Frequency & Percent & Valid Percent & $\begin{array}{l}\text { Cumulative } \\
\text { Percent }\end{array}$ \\
\hline \multirow{4}{*}{ Valid } & $4-6$ & 6 & 24.0 & 24.0 & 24.0 \\
& $7-9$ & 5 & 20.0 & 20.0 & 44.0 \\
& $13-12$ & 6 & 24.0 & 24.0 & 68.0 \\
& $16-18$ & 4 & 16.0 & 16.0 & 84.0 \\
& Total & 25 & 16.0 & 16.0 & 100.0 \\
\hline
\end{tabular}

Penguasaan struktur kalimat ternyata ada 11orang siswa (44\%) yang memiliki penguasaan struktur kalimat yang rendah. Dari distribusi frekuensi penguasaan struktur kalimat ada sebanyak 6 orang siswa (24\%) memiliki penguasaan struktur kalimat sedang, dan sebanyak 8 orang siswa (32\%) memiliki penguasaan struktur kalimat yang tinggi.Berdasarkan tabel di atas, dapat dibuat histogram frekuensi penguasaan struktur kalimat sebagai berikut di bawah ini.

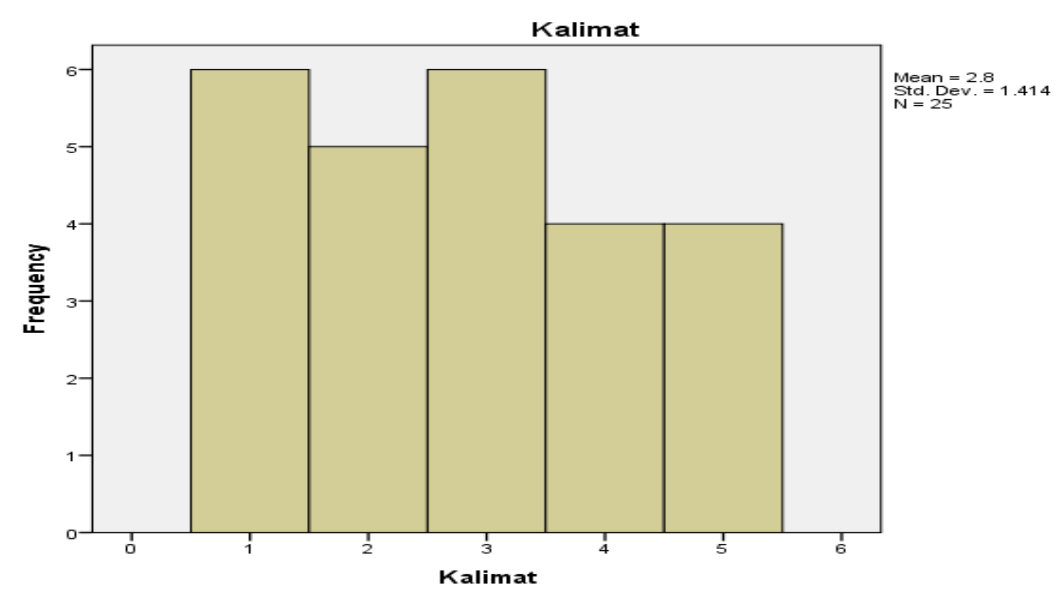

Data tentang membaca pemahaman berkisar antara 59 sampai 95, dengan ratarata 77,36. Data kemampuan menulis karangan narasi menunjukkan bahwa 9 orang siswa (36\%) yang memiliki kemampuan menulis narasi rendah, ada 8 orang siswa (32\%) memiliki kemampuan menulis narasi sedang, dan sebanyak 8 orang siswa 
(32\%) memiliki kemampuan menulis karangan narasi yang tinggi. Sebaran data tentang menulis karangan narasi pada siswa Kelas IV SD Muhammadiyah PK Rabbani Kecamatan Karanganom Kabupaten Klaten Tahun Pelajaran 2018/2019 tampak pada tabel sebagai berikut di bawah ini.

\begin{tabular}{|c|c|c|c|c|c|}
\hline & & Frequency & Percent & Valid Percent & $\begin{array}{c}\text { Cumulative } \\
\text { Percent }\end{array}$ \\
\hline \multirow{7}{*}{ Valid } & 59-64 & 5 & 20.0 & 20.0 & 20.0 \\
\hline & $65-70$ & 4 & 16.0 & 16.0 & 36.0 \\
\hline & $71-76$ & 2 & 8.0 & 8.0 & 44.0 \\
\hline & $77-83$ & 6 & 24.0 & 24.0 & 68.0 \\
\hline & $84-89$ & 3 & 12.0 & 12.0 & 80.0 \\
\hline & $90-95$ & 5 & 20.0 & 20.0 & 100.0 \\
\hline & Total & 25 & 100.0 & 100.0 & \\
\hline
\end{tabular}

Berdasarkan tabel di atas, dapat dibuat histogram frekuensi kemampuan karangan narasi sebagai berikut :

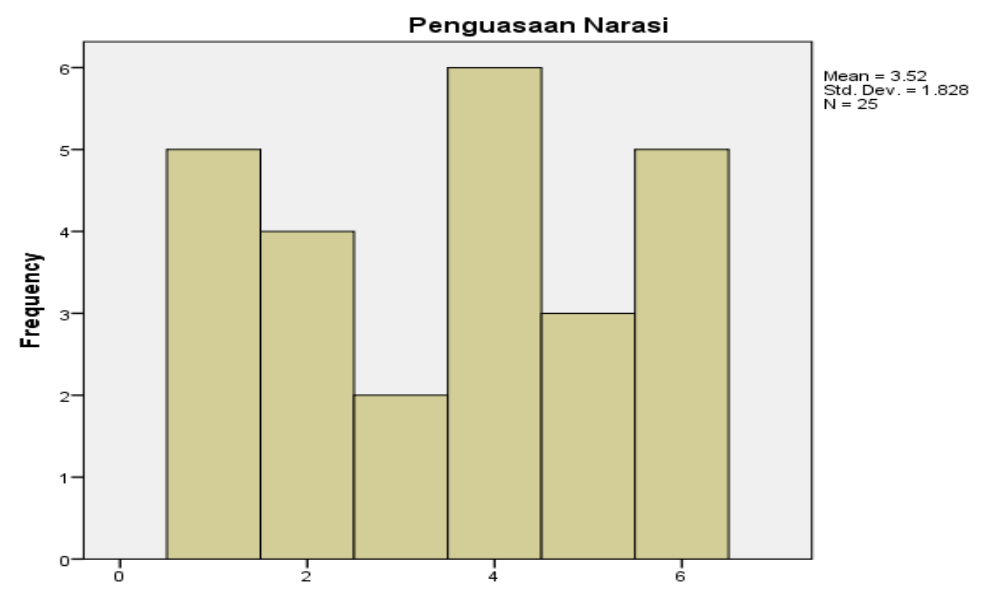

\section{Pengujian Persyaratan Analisis}

\section{Pengujian Normalisasi}

\section{Uji normalitas variabel penguasaan kosakata $\left(\mathrm{X}_{1}\right)$}

Uji normalitas data dilakukan dengan menggunakan teknik Kolmogorov

Smirnov. Berdasarkan hasl uji normalitas data dengan menggunakan Uji Komogorov Smirnov diperoleh hasil penguasaan kosakatabahwa nilai sinifikansi sebesar 0,474> 
dari nilai alfa yaitu sebesar 0,05 . Hal ini berarti bahwa data tentang penguasaan kosakatadari populasi yang berdistribusi normal.

\section{Uji normalitas variabel penguasaan struktur kalimat $\left(\mathrm{X}_{2}\right)$}

Uji normalitas data variabel penguasaan struktur kalimat dilakukan dengan menggunakan teknik uji Kolmogorov Smirnov. Pengujian normalitas terhadap data penguasaan kosakata menghasilkan nilai signifikansi sebesar 0,966 lebih besar dari nilai alfa tabel yaitu 0,05 sehingga dapat disimpulkan bahwa data variabel penguasaan kalimat berasal dari populasi yang berdistribusi normal.

\section{Uji normalitas variabel kemampuan menulis karangan narasi (Y)}

Uji normalitas ada variabel kemampuan menulis karangan narasi dilakukan dengan menggunakan teknik uji Kolmogorov Smirnov (Sudjana, 1992 : 466-467). Pengujian normalitas terhadap data kemampuan membaca pemahaman menghasilkan nilai signifikansi sebesar 0,881 lebih besar dari nilai alfa sebesar 0,05 sehingga dapat disimpulkan bahwa data variabel kemampuan menulis narasi berasal dari populasi yang berdistribusi normal. Terkait dengan uji normalitas penguasaan kosakata, struktur kalimat dengan menulis narasi pada tabel sebagai berikut.

One-Sample Kolmogorov-Smirnov Test

\begin{tabular}{|c|c|c|c|c|}
\hline & & Kosakata & Kalimat & Narasi \\
\hline $\mathrm{N}$ & & 25 & 25 & 25 \\
\hline \multirow{3}{*}{ Normal Parameters ${ }^{\mathrm{a}, \mathrm{b}}$} & Mean & 11.80 & 10.40 & 77.36 \\
\hline & Std. Deviation & 4.340 & 4.082 & 11.346 \\
\hline & Absolute & .169 & .099 & .117 \\
\hline \multirow[t]{2}{*}{ Most Extreme Differences } & Positive & .075 & .099 & .102 \\
\hline & Negative & -.169 & -.091 & -.117 \\
\hline Kolmogorov-Smirnov Z & & .845 & .497 & .587 \\
\hline Asymp. Sig. (2-tailed) & & .474 & .966 & .881 \\
\hline
\end{tabular}

\section{Uji Linieritas}

Hasil analisis regresi sederhana penguasaan kosakata atas menulis karangan narasiperlu diuji kelinearannya. Berdasarkan hasil uji linearitas garis regresi hasil Deviation from Linearity diperoleh $F_{h i t u n g}=2,620$ dengan nilai signifikansi 0,061. 
Karena nilai signifikansi lebih besar daripada 0,05, maka terima Ho dan tolak H1.

Dengan demikian dapat disimpulkan bahwa garis regresi linear. Dalam penelitian ini uji linieritas dilakukan menggunakan uji $\mathrm{F}$ dengan bantuan program SPSS versi 20.0 .

\section{ANOVA Table}

\begin{tabular}{|c|c|c|c|c|c|c|c|}
\hline & & & Sum of Squares & df & $\begin{array}{l}\text { Mean } \\
\text { Square }\end{array}$ & $\mathrm{F}$ & Sig. \\
\hline Karasi & $\begin{array}{l}\text { Between } \\
\text { Groups } \\
\text { Within Groups } \\
\text { Total }\end{array}$ & $\begin{array}{l}\text { (Combined) } \\
\text { Linearity } \\
\text { Deviation } \\
\text { from } \\
\text { Linearity }\end{array}$ & $\begin{array}{l}2872.510 \\
2251.499 \\
621.011 \\
217.250 \\
3089.760\end{array}$ & $\begin{array}{l}11 \\
24\end{array}$ & $\begin{array}{l}220.962 \\
2251.499 \\
51.751 \\
19.750\end{array}$ & $\begin{array}{l}11.188 \\
114.000 \\
2.620\end{array}$ & $\begin{array}{l}.000 \\
.000\end{array}$ \\
\hline
\end{tabular}

Hasil analisis regresi sederhana penguasaan struktur kalimat atas menulis karangan narasiperlu diuji kelinearannya. Hasil analisis regresi sederhana berdasarkan hasil uji linearitas garis regresi hasil Deviation from Linearity diperoleh $F_{\text {hitung }}=2,129$ dengan nilai signifikansi 0,634. Karena nilai signifikansi 0,634 lebih besar daripada 0,05, maka terima Ho dan tolak H1. Dengan demikian dapat disimpulkan bahwa garis regresi linear. Hasil uji linieritas dilakukan menggunakan uji $\mathrm{F}$ dengan bantuan program SPSS versi 20.0. sebagai berikut.

\section{ANOVA Table}

\begin{tabular}{|c|c|c|c|c|c|c|c|}
\hline & & & $\begin{array}{l}\text { Sum of } \\
\text { Squares }\end{array}$ & $\mathrm{df}$ & Mean Square & $\mathrm{F}$ & Sig. \\
\hline $\begin{array}{l}\text { Narasi * } \\
\text { Kalimat }\end{array}$ & $\begin{array}{l}\text { Between } \\
\text { Groups } \\
\text { Within Gr } \\
\text { Total }\end{array}$ & $\begin{array}{l}\text { (Combined) } \\
\text { Linearity } \\
\text { Deviation } \\
\text { from } \\
\text { Linearity } \\
\text { ups }\end{array}$ & $\begin{array}{r}2210.927 \\
1426.573 \\
784.354 \\
878.833 \\
3089.760\end{array}$ & $\begin{array}{l}11 \\
24\end{array}$ & $\begin{array}{r}170.071 \\
1426.573 \\
65.363 \\
79.894\end{array}$ & $\begin{array}{r}2.129 \\
17.856 \\
.818\end{array}$ & $\begin{array}{l}.109 \\
.001\end{array}$ \\
\hline
\end{tabular}




\section{Pengujian Hipotesis}

Pengujian hipotesis pertama dan kedua dilakukan dengan menggunakan teknik korelasi Product Moment dari Pearson. Sedangkan untuk menguji hipotesis ketiga digunakan teknik analisis korelasi ganda yang bertujuan untuk mengetahui hubungan kedua variabel bebas dengan variabel terikat secara bersama-sama dan untuk uji signifikansi dengan menggunakan uji T. Analisis korelasi parsial antara penguasaan kosakata (X1) dengan kemampuan menulis narasi (Y) diperoleh dari koefisien sebesar 0,771. Untuk mengetahui Koefisien korelasi parsial antara Kosakata dan Narasi dilakukan uji t dengan bantuan aplikasi SPSS versi 20.0 dengan hasil sebagai berikut.

\section{Correlations}

\begin{tabular}{|c|c|c|c|}
\hline Control Variables & & Narasi & Kosakata \\
\hline & Correlation & 1.000 & .771 \\
\hline Narasi & Significance (2-tailed) & & .000 \\
\hline & df & 0 & 22 \\
\hline 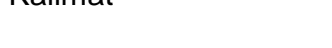 & Correlation & .771 & 1.000 \\
\hline Kosakata & Significance (2-tailed) & .000 & . \\
\hline & df & 22 & 0 \\
\hline
\end{tabular}

Untuk mengetahui koefisien korelasi parsial antara penguasaan struktur kalimat dan menulis karangan narasi dilakukan uji t dengan bantuan aplikasi SPSS versi 20.0 dengan hasil sebagai berikut.

\section{Correlations}

\begin{tabular}{|c|c|c|c|}
\hline \multicolumn{2}{|l|}{ Control Variables } & Narasi & Kalimat \\
\hline \multirow{6}{*}{ Kosakata } & Correlation & 1.000 & .441 \\
\hline & Significance (2-tailed) & & .031 \\
\hline & df & 0 & 22 \\
\hline & Correlation & .441 & 1.000 \\
\hline & Significance (2-tailed) & .031 & . \\
\hline & df & 22 & 0 \\
\hline
\end{tabular}

Analisis korelasi parsial antara antara penguasaan kalimat dan narasi diperoleh koefisien korelasi sebesar 0,441. Dari hasil pengujian tersebut menunjukkan bahwa Signifikansi $0,031<0,05$ maka terdapat hubungan antara penguasaan struktur kalimat 
dengan menulis karangan narasi. Oleh karena itu, berdasarkan hasil analisisi tersebut diatas dapat dikatakan ada hubungan yang positif antara penguasaan struktur kalimat dengan menulis karangan narasi.

Untuk mengetahui hubungan antara penguasaan kalimat terhadap kemampuan menulis narasi, maka dilakukan analisis hubungan antara ketiga variabel dengan analisisi korelasi ganda. Analisisi korelasi dilakukan untuk mengetahui apakah ada kaitan antara variabel penguasaan kosakata dan kalimat terhadap kemampuan menulis narasi.

Analisis korelasi ganda menunjukkan bahwa penguasaan kosakata dan struktur kalimat memberikan kontribusi terhadap menulis karangan narasi sebesar 0,781. Koefisien korelasi ganda antara penguasaan kosakata dan struktur kalimat terhadap kemampuan menulis karangan narasi adalah 0,884. Berdasarkan hasil analisis tersebut diatas Sig. 0,000<0,05 maka dapat disimpulkan bahwa terdapat signifikansi persamaan regresi linier ganda antara penguasaan kosa kata dan penguasaan struktur kalimat mempunyai hubungan secara bersama-sama terhadap kemampuan menulis karangan narasi.

\begin{tabular}{llcc}
\hline No & \multicolumn{1}{c}{ Nama Prediktor } & Sumbangan Relatif (\%) & $\begin{array}{c}\text { Sumbangan } \\
\text { Efektif (\%) }\end{array}$ \\
\hline 1 & $\begin{array}{l}\text { Penguasaan Kosakata } \\
(\mathrm{X} 1)\end{array}$ & $75,7 \%$ & $59,16 \%$ \\
\hline 2 & $\begin{array}{l}\text { Penguasaan Struktur } \\
\text { Kalimat (X2) }\end{array}$ & $24,3 \%$ & $19,01 \%$ \\
\hline & & $100 \%$ & $78,1 \%$. \\
\hline
\end{tabular}

Dari tabel di atas dapat dilihat bahwa variabel penguasaan kosakata memberikan sumbangan efektif terhadap kemampuan menulis karangan narasi $59,16 \%$ sedangkan variabel penguasaan struktur kalimat memberikan sumbangan efektif terhadap kemampuan menulis karangan narasi sebesar 19,01\%. Oleh karena itu, dapat disimpulkan bahwa total sumbangan penguasaan kosakata (X1) dan penguasaan struktur kalimat (X2) ke menulis karangan narasi (Y) sebesar 78,17\%, artinya nilai menulis karangan narasi (Y) dipengaruhi oleh penguasaan kosakata (X1) dan penguasaan struktur kalimat (X2) sebesar 78,17\%, sisanya dipengaruhi oleh variable lain. Oleh karena itu, total sumbangan efektif penguasaan kosakata (X1) dan penguasaan struktur kalimat (X2) sama dengan Rsquare=0,781 atau 78,1\%. 


\section{Pembahasan Hasil Penelitian}

\section{Hubungan Penguasaan Kosakata dengan Kemampuan Menulis Karangan Narasi}

Uji hipotesis pertama dengan menggunakan bantuan komputer program SPSS versi 20.0 menunjukkan bahwa signifikansi $0,000<0,05$ maka terdapat hubungan antara penguasaan kosakata dengan menulis karangan narasi. Dari hasil perhitungan dengan bantuan komputer program SPSS 20.0, maka dapat disimpulkan bahwa $\mathrm{H}_{1}$ diterima artinya terdapat hubungan yang positif dan signifikan antara penguasaan kosakata terhadap kemampuan menulis karangan narasi. Jika dipresentasikan bahwa penguasaan kosakata memiliki sumbangan efektif sebesar 59,16\% kemampuan menulis karangan narasi siswa kelas IV SD Muhamamdiyah PK Rabbani Tahun Pelajaran 2018/2019. Berdasarkan uraian di atas, maka diketahui bahwa penguasaan kosakata yang baik akan meningkatkan kemampuan menulis karangan narasi. Menurut Fahrurrozi (2017:124-133) hubungan penguasaan pemilihan kosakata/diksi dan berpikir kreatif dengan kemampuan menulis narasif sangatlah erat.

Rianti, Maya, Irfani Basri, dan Nursaid (2013) menyampaikan dalam penelitiannya bahwa siswa hendaknya dapat melatih diri agar lebih menguasai kosakata dengan cara rajin membaca. Jika siswa mempunyai penguasaan kosakata yang rendah maka siswa sulit menyusun dan merangakai kata menjadi sebuah kalimat, sehingga variasi kalimat dalam menulis karangan narasi siswa tidak beraturan. Sebaliknya, jika siswa mempunyai penguasaan kosakata yang tinggi maka siswa mudah menyusun dan merangkai kata dengan pola struktur kalimat yang benar. Siswa juga pandai membuat variasi kalimat dalam menulis karangan narasi secara kronologis.

\section{Hubungan Penguasaan Struktur Kalimat dengan Kemampuan Menulis Narasi}

Uji hipotesis kedua dengan menggunakan bantuan komputer program SPSS 20.0 diperoleh Analisis korelasi parsial antara antara penguasaan kalimat dan menulis karangan narasi diperoleh koefisien korelasi sebesar 0,441. Dari hasil pengujian tersebut menunjukkan bahwa signifikansi $0,031<0,05$ maka terdapat hubungan antara penguasaan struktur kalimat dengan menulis karangan narasi. Oleh karena itu, 
berdasarkan hasil analisisi tersebut diatas dapat dikatakan ada hubungan yang positif antara penguasaan struktur kalimat dengan menulis karangan narasi. Jika dipresentasikan bahwa variabel penguasaan struktur kalimat memberikan sumbangan efektif terhadap kemampuan menulis karangan narasi sebesar 19,01\% siswa kelas IV SD Muhamamdiyah PK Rabbani Tahun Pelajaran 2018/2019.

Berdasarkan uraian di atas diketahui bahwa struktur kalimat berhubungan erat dengan peningkatan kemampuan menulis karangan narasi. Hal ini sejalan dengan pendapat Munirah \& Hardian (2016 :78-87) yang mengatakan penguasaan kosa kata dan struktur kalimat merupakan dua komponen yang saling berkaitan. Penguasaan kosakata dan struktur kalimat merupakan suatu syarat untuk dapat terampil berbahasa, yaitu terampil menyimak, berbicara, membaca, dan menulis. Keberhasilan siswa pada setiap mata pelajaran ditentukan oleh perbendaharaan kosakata dan struktur kalimat yang dimilikinya. Berdasarkan paparan di atas dapat dikatakan bahwa penguasaan struktur kalimat bagi siswa di sekolah dasar menyumnbang peran penting dalam praktik berbahasa, yaitu menulis sebuah karangan narasi.

\section{Hubungan Penguasaan Kosakata dan Struktur Kalimat dengan Kemampuan Menulis Karangan Narasi}

Uji hipotesis ketiga dengan menggunakan bantuan komputer program SPSS versi 20.0 diperoleh koefisien korelasi ganda antara penguasaan kosakata dan struktur kalimat terhadap kemampuan menulis karangan narasi adalah 0,884. Berdasarkan hasil analisis tersebut diatas Sig. 0,000<0,05 maka dapat disimpulkan bahwa terdapat signifikansi persamaan regresi linier ganda antara penguasaan kosa kata dan penguasaan struktur kalimat mempunyai hubungan secara bersama-sama terhadap kemampuan menulis karangan narasi.

Analisis korelasi ganda menunjukkan bahwa penguasaan kosakata dan struktur kalimat memberikan kontribusi terhadap menulis karangan narasi sebesar 0,781. Dari data penelitian diketahui bahwa variabel penguasaan kosakata memberikan sumbangan efektif terhadap kemampuan menulis karangan narasi 59,16\% sedangkan variabel penguasaan struktur kalimat memberikan sumbangan efektif terhadap kemampuan menulis karangan narasi sebesar 19,01\%. 
Dapat disimpulkan bahwa total sumbangan penguasaan kosakata (X1) dan penguasaan struktur kalimat (X2) kepada menulis karangan narasi (Y) sebesar 78,17\%, artinya nilai menulis karangan narasi (Y) dipengaruhi oleh penguasaan kosakata (X1) dan penguasaan struktur kalimat (X2) sebesar 78,17\%, sisanya dipengaruhi oleh variable lain. Total sumbangan efektif penguasaan kosakata (X1) dan penguasaan struktur kalimat (X2) sama dengan Rsquare=0,781 atau 78,1\%.

Dari uraian di atas diketahui bahwa penguasaan kosakata (X1) dan penguasaan struktur kalimat berhubungan erat dengan menulis karangan narasi. Penguasaan kosakata dan struktur kalimat merupakan suatu syarat untuk dapat terampil berbahasa, yaitu terampil menyimak, berbicara, membaca, dan menulis. Berdasarkan hasil penelitian dan pendapat ahli di atas menunjukkan bahwa terdapat hubungan positif dan signifikan antara penguasaan kosakata dan struktur kalimat dengan menulis narasi bahasa Indonesia pada siswa kelas IV SD Muhamamdiyah PK Rabbani Tahun Pelajaran 2018/2019.

\section{Keterbatasan Penelitian}

Penelitian ini telah dilaksanakan sebaik mungkin dan dengan hasil penghitungan statistik terhadap variabel-variabel penelitian dengan margin errornya hanya 0,5 tetapi memiliki keterbatasan, anatara lain: (1) Faktor yang diteliti yang berhubungan dengan kemampuan menulis narasi hanya dua variabel, yaitu: penguasaan kosakata dan struktur kalimat. Padahal masih banyak faktor lain yang mempengaruhi kemampuan menulis narasi. (2) Kurang representatifnya materi yang diteskan (tidak meliputi seluruh aspek kosakata dan struktur kalimat). Selain itu ada ketidakcocokan antara apa yang dibelajarkan guru dengan apa yang diujikan sangat memungkinkan kondisi ini terjadi. (3) Dalam pengambilan data dengan menggunakan teknik tes objektif, ada kemungkinan siswa mencontoh pekerjaan temannya. Meskipun ketika di lapangan, peneliti sudah menghimbau kepada responden untuk mmeberikan jawaban sejujurnya terhadap setiap butir pertanyaan, serta menegaskan bahwa jawaban yang diberikan tidak berhubungan dengan hasil studi atau nilai dalam pembelajaran setiap harinya. (4) Waktu kesempatan siswa dalam menjawab tiga jenis instrumen tes, dari mulai soal penguasaan kosakata, struktur kalimat, dan menulis karangan narasi membutuhkan konsentrasi yang lama sehingga ada siswa yang jenuh, 
meskipun disela-sela pergantian tes, peneliti sudah mengantisipasi dengan memberikan kesempatan istirahat dan ice breaking.

\section{SIMPULAN}

Terdapat hubungan yang positif antara penguasaan kosakata, struktur kalimat dengan menulis karangan narasi siswa kelas IV SD Muhammadiyah PK Rabbani Kecamatan Karanganom Kabupaten Klaten Tahun Pelajaran 2018/2019. Analisis korelasi sederhana untuk mengetahui hubungan antara Penguasaan Kosakata dengan Narasi. Analisis korelasi parsial antara penguasaan kosakata (X1) dengan kemampuan menulis narasi (Y) diperoleh dari koefisien sebesar 0,771. Analisis korelasi parsial antara antara penguasaan kalimat dan narasi diperoleh koefisien korelasi sebesar 0,441 .

Analisis korelasi ganda menunjukkan bahwa penguasaan kosakata dan struktur kalimat memberikan kontribusi terhadap menulis karangan narasi sebesar 0,781. Koefisien korelasi ganda antara penguasaan kosakata dan struktur kalimat terhadap kemampuan menulis karangan narasi adalah 0,884. Berdasarkan hasil analisis tersebut diatas Sig. 0,000<0,05 maka dapat disimpulkan bahwa terdapat signifikansi persamaan regresi linier ganda antara penguasaan kosa kata dan penguasaan struktur kalimat mempunyai hubungan secara bersama-sama terhadap kemampuan menulis karangan narasi. Pada variabel penguasaan kosakata memberikan sumbangan efektif terhadap kemampuan menulis karangan narasi sebesar 59,16\% sedangkan variabel penguasaan struktur kalimat memberikan sumbangan efektif terhadap kemampuan menulis karangan narasi sebesar 19,01\%. Total sumbangan penguasaan kosakata dan struktur kalimat ke kemampuan menulis karangan narasi sebesar 78,17\%. Ini berarti nilai menulis karangan narasi dipengaruhi oleh penguasaan kosakata dan struktur kalimat sebesar 78,17\%,

\section{DAFTAR PUSTAKA}

Abidin, Yunus. (2012). Pembelajaran Bahasa Berbasis Pendidikan Karakter. Bandung: PT Refika Aditama.

Afifah, Anis. (2019). Hubungan Antara Minat Baca dan Kemampuan Penguasaan Kosakata dengan Kemampuan Membaca Pemahaman Di SMP N 1 Pedan Tahun Pelajaran 2018/2019. Tesis. Pasca Sarjana Unwidha. 
Journal Homepage: http://journal.ikippgriptk.ac.id/index.php/bahasa Jurnal Pendidikan Bahasa, Vol. 8, No. 2, December 2019 Copyright (C) IKIP PGRI Pontianak

Chaer, Abdul. (2011). Ragam Bahasa Ilmiah. Jakarta: Rineka Cipta.

Dalman. (2015). Keterampilan Menulis. Jakarta: Rajawali Pers.

Darminto, Riyo. (2014). Hubungan antara Penguasaan Kosa Kata dan Kalimat Efektif dengan Keterampilan Menulis Narasi Siswa Kelas V SDN Wonokusumo V Surabaya. E-Journal Dinas Pendidikan Kota Surabaya. 7. ISSN 2337-3253.

Depdiknas, (2013). Dokumen Kurikulum 2013 Sekolah Dasar/Madrasah Ibtidaiyah. Jakarta: CV.Sahabat.

Djiwandono, Soenardi. (2011). Tes Bahasa Pegangan bagi Pengajar Bahasa. Malang: PT Indeks.

Doyin dan Wagiran. (2009). Bahasa Indonesia Pengantar Penulisan Karya Ilmiah. Semarang: UNNES PRESS.

Effendi S, Djoko Kentjono, dan Basuki Suhardi. (2015). Tata Bahasa Dasar Bahasa Indonesia. Bandung: Remaja Rosdakarya

Haryanto, Wasis. (2013). Hubungan Antara Penguasaan Kosakata dan Motivasi Belajar dengan Kemampuan Menulis Pidato (Survei pada siswa kelas VI SD Negerai Gugus "DR Soetomo”, Kecamatan Mandiraja, Kabupaten Banjarnegara). Tesis.Pasca Sarjana UNWIDHA.

Hastuti, Nining Yuni. (2012). Hubungan Antara Penguasaan Kosakata Dan Struktur Kalimat Dengan Keterampilan Menulis Deskripsi Siswa Kelas XI SMK Tunggal Cipta Manisrenggo Kabupaten Klaten Tahun Pelajaran 2011/2012. Tesis. Pasca Sarjana UNWIDHA.

Iskandarwassid dan Dadang Sunendar. (2015). Strategi Pembelajaran Bahasa. Bandung: PT Remaja Rosdakarya.

Ismawati, Esti. (2016). Metode Penelitian Pendidikan Bahasa dan Sastra. Yogyakarta: Ombak.

Mulyani, Sri.(2009).Hubungan Antara Penguasaan Kosakata dan Tata Bahasa dengan Keterampilan Berpidato Pada Siswa Kelas IX SMP Negeri Cawas Kabupaten Klaten Tahun Pelajaran 2008/2009. Tesis. Pasca Sarjana UNWIDHA.

Munirah Dan Hardian. (2016). "Pengaruh Kemampuan Kosakata dan Struktur Kalimat Terhadap Kemampuan Menulis Paragraf Deskripsi Siswa SMA“. Jurnal Pendidikan Bahasa dan Sastra,Volume 16, Nomor 1, April 2016, Hlm. 78-87 Universitas Muhammadiyah Makassar 
Muslich, M. (2010). Garis-garis besar tatabahasa baku bahasa Indonesia. Bandung: Refika Aditama.

Noermanzah. (2017). Struktur Kalimat Tunggal Bahasa Sindang Di Kota Lubuklinggau dan Pengaruhnya dalam Pembelajaran Bahasa IndonesiaAKSIS Jurnal Pendidikan Bahasa dan Sastra Indonesia Volume 1 Nomor 1, Juni 2017 e-ISSN: 2580-9040 e-Journal: http://doi.org/10.21009/AKSIS

Nurgiyantoro, Burhan. (2014). Penilaian Pembelajran Bahasa Berbasis Kompetensi. Yogyakarta: BPFE-Yogyakarta.

Rianti, Maya, Irfani Basri\&Nursaid. (2013). Hubungan Penguasaan Kosakata Dengan Kemampuan Menulis Karangan Argumentasi Siswa Kelas XI IPS Sma Negeri 1 Guguak Kabupaten 50 Kota Program Studi Pendidikan Bahasa Dan Sastra Indonesia. FBS Universitas Negeri Padang.

Samsiyah, Siti dkk. (2013). Hubungan antara Penguasaan Kosakata dan Motivasi Belajar dengan Kemampuan Membaca Cerita (Survei pada Siswa Kelas V SD Negeri di Kecamatan Jatiroto).Jurnal Pendidikan Bahasa. 1 (1). ISSN 1693-623X.

Setyawan, Arief dkk. (2015). Hubungan antara Penguasaan Kosakata dan Motivasi Belajar dengan Keterampilan Menulis Teks Narasi pada Siswa Kelas XI SMK Negeri 1 Sawit Boyolali Tahun Ajaran 2014/2015. Jurnal Penelitian Bahasa, Sastra Indonesia dan Pengajarannya. 3 (2). ISSN I2302-6405.

Sitompul, Elsa Yusrika, (2013). Theaching vocabulary using Flascards and Wort List. Journal of English and Education 2013 1(1), hlm. 52-58.

Sukoyo, Joko. (2013). Hubungan Penguasaan Kosakata dan Minat Membaca dengan Kemampuan Menulis Eksposisi Mahasiswa Program Studi Pendidikan Bahasa dan Sastra Jawa UNNES.Jurnal LINGUA IX (1). ISSN 18299342.

Suparno dan Mohamad Yunus. (2008). Materi Pokok Keterampilan Dasar Menulis. Jakarta: Universitas Terbuka.

Yunus, Syarifudin. (2015). Kompetensi Menulis Kreatif. Bogor: Ghalia Indonesia. Zainurrahman. (2011). Menulis dari Teori Hingga Praktik. Bandung: Alfabeta. 